\title{
The Current Status of Ticks in Turkey: A 100-Year Period Review from 1916 to 2016
}

\author{
Türkiye’de Kenelerin Mevcut Durumu: 1916-2016 Yılları Arasındaki Yüzyıllık Periyoda
}

Dayanan Bir Derleme

\section{Abdullah İnci, Alparslan Yıldırım, Önder Düzlü}

Vectors and Vector-Borne Diseases Research and Implementation Center, Erciyes University, Kayseri, Türkiye

\section{ABSTRACT}

Environmental and bio-ecological changes, some administrative and political mistakes, and global warming seriously affect the behaviors of ticks in Turkey and globally. The global public sensitivity toward tick infestations has increased along with increases in tick-borne diseases (TBDs). Recently, the World Health Organization (WHO) developed a new political concept, "One Health," for specific struggle strategies against tick infestations and TBDs. To highlight the importance of the issue, the WHO had declared the year 2015 for vector-borne diseases and adopted the slogan "small bites big threat". In global struggle strategies, the epidemiological aspects and dynamics of increasing tick populations and their effects on the incidence of the TBDs mainly with zoonotic characteristics have been specifically targeted. In Turkey, during the last century, approximately 47 tick species, including eight soft and 39 hard tick species in three and six genera belonging to Argasidae and lxodidae, respectively, had already been reported. In this article, the recorded tick species, regional infestations, and medical and veterinary importance in Turkey were chronologically reviewed based on a 100-year period between 1916 and 2016.

Keywords: A century-old period, current status, ticks, Turkey

Received: 08.06.2016 Accepted: 28.08.2016

\section{Öz}

Tüm dünyada olduğu gibi Türkiye'de de çevresel ve biyo-ekolojik değişiklikler, bazı idari ve politik hatalar ile küresel ısınma kenelerin davranışlarını ciddi bir şekilde etkilemektedir. Kene enfestasyonlarına ve kene ile bulaşan hastalıklara karşı halkın duyarlılığı küresel manada artmıştır. Bu noktada son yıllarda Dünya Sağlık Örgütü (WHO), keneler ve kenelerle bulaşan hastalıklara karşı spesifik mücadele stratejileri üzerine "Tek Sağlık" adı altında yeni bir konsept geliştirmiştir. Bu konunun önemini vurgulamak için WHO, 2015 yılını vektör-borne hastalıklar yılı olarak deklare etmiş ve "küçük ısııık büyük tehdit" şeklinde slogan geliştirmiştir. Küresel mücadele stratejileri arasında, kene popülasyonlarının artış dinamikleri ve epidemiyolojik bakış açısını açıkça ortaya koyma ve özellikle zoonotik karakterli kene kaynaklı hastalıkların insidensi üzerine kenelerin etkileri gibi konular özellikle hedef alınmıştır. Son yüzyılda Türkiye'de, argasidae ve ixodidae ailelerine ait sırasıyla üç ve altı soyda sekiz argasid ve otuz dokuz ixodid kene türünü kapsayan toplam kırk yedi kene türü rapor edilmiştir. Bu derlemede, Türkiye'de 1916 ve 2016 yılları arasındaki yüzyıllık periyotta, varlığı bildirilen kene türleri, bunların bölgesel ve mevsimsel dağılşları ile medikal ve veteriner önemleri gözden geçirilmiştir.

Anahtar Kelimeler: Yüzyıllık periyot, mevcut durum, keneler, Türkiye

Geliş Tarihi: 08.06.2016 Kabul Tarihi: 28.08.2016

\section{INTRODUCTION}

Turkey is a peninsula subtropically located between the $36^{\circ}$ and $42^{\circ}$ northern parallels and $26^{\circ}$ and $45^{\circ}$ eastern meridians on the Mediterranean, Aegean, and Black seas in Eurasia. It covers $783.582 \mathrm{~km}^{2}$ has a human population of over 80 million and a livestock population of over 50 million; its economic structure currently depends on a mix of industrial and agricultural products. The location of Turkey allows it to be a natural bridge for the transmission of some tick species and also several tick-borne diseases (TBDs) from Africa to Europe and from Europe to Africa. In particular, migratory birds play an important role for this intercontinen-

Address for Correspondence/ Yazışma Adresi: Dr. Abdullah Inci E.mail: ainci@erciyes.edu.tr DOI: $10.5152 /$ tpd.2016.4844

CCopyright 2016 Turkish Society for Parasitology - Available online at www.tparazitolderg.org

CTelif hakkı 2016 Türkiye Parazitoloji Derneği - Makale metnine www.tparazitolderg.org web sayfasından ulaşılabilir. 
tal transmission of ticks and TBDs. Turkey has many valuable marshes and migratory bird stations in different geographical regions; these include the following: the "Büyük Menderes Delta" in the Aegean region, the "Sultan Marshes" in Central Anatolia, the "Manyas Bird Paradise" in Marmara, the "Kızılırmak Delta" in the Black Sea, the "Hevsel Bird Paradise" in the Southeast, and the "Aras Bird Paradise" in the North-eastern regions of Turkey. All of them highlight the intercontinental importance for the epidemiology of ticks and TBDs. Turkey covers several geographical regions such as Marmara, the Black Sea, Eastern Anatolia, South-eastern Anatolia, the Mediterranean, the Aegean, and Central Anatolia. A typical continental climate prevails in the plateaus of Anatolia, whereas temperate climates mainly dominate the coastal areas. However, each geographical region has different specific climatic conditions, vegetation structures, and wildlife, allowing suitable habitats for various tick species in all four seasons of the year. During tick seasons, several tick-borne pathogens, such as parasites, virus, and bacteria, are transmitted to their hosts by their specific vector ticks and cause very serious TBDs. Additionally, because of global warming, the temperate climate of Turkey affects the prevalence of various parasitic arthropod infestations and different emerging and re-emerging vector-borne diseases with zoonotic characteristics in some regions of Turkey. Approximately more than 40 of these vector-borne diseases have already been reported in humans, animals, and plants in Turkey $(1,2)$. These tick infestations and tick-borne pathogens might be most prevalent and seriously dangerous for public and livestock health, particularly in the tick seasons, in most parts of Turkey. Tick infestations and TBDs are the major impediment for the development and improvement of the livestock industry in Turkey, as well as in many other countries, and cause very serious economic losses of livestock by decreasing milk production, animal loss of weight, or increasing risk factors for bacterial and fungal infections as well as screw-worm attacks (3-5). Globally, it has been reported that $80 \%$ of 1.2 million cattle are at a risk of tick infestations and TBDs, causing losses of US $\$ 7$ billion, annually (6).

In this article, the recorded tick species and their regional distribution and infestations in man and animals and also the identified tick-borne pathogens in Turkey have been chronologically reviewed between 1916 and 2016.

\section{Current status of tick species}

In Turkey, preliminary taxonomic studies about ticks were performed as early as the beginning of the 1900s. The initial records about tick fauna in Turkey are based on Ixodes ricinus var. gibbosus n. var., Haemaphysalis cinnabarina var. punctate, and Hyalomma aegyptium ticks, and were collected from a domestic goat (Capra hircus) in November 1913 in the Izmir province of the Aegean region by Nuttall (7) in 1916. In the following decades, Ixodes ricinus and Hyalomma aegyptium were reported by Celebi (8) in 1926; Ornithodoros lahorensis was reported by Tuzdil (9) in 1936; Rhipicephalus rossicus was reported by Pomerantzev (10) in 1946 from Eastern Anatolia; and Rhipicephalus bursa, R. sanguineus, R. (Boophilus) calcaratus, $H$. dromedarii, $H$. anatolicum, Hae. concinna, and Dermacentor reticulatus were recorded by Oytun (11) in 1947 from livestock in Central Anatolia. In addition to the tick species mentioned above, a lot of argasid and ixodid ticks such as Argas reflexus, A. persicus, Hae. parva, Hae. inermis, Hae. sulcata, Hae numidiana, D. niveus, $H$. detritum, and $H$. excavatum were recognized by Kurtpinar (12) in 1954 from domesticated animals in the seven regions; $H$. mauritanicum was reported by Yasarol (13) in 1954; O. erraticus was collected from rodent holes at in southern Turkey at the Turkey-Syria border by Ozsan and Akyay (14) in 1954; I. vespertilionis was reported from Vespertilian bats by Arthur (15) in 1956; Hae. erinacei and Hyalomma impeltatum were reported in the Marmara region by Hoogstraal (16) in 1959; Ablyomma variegatum was reported from a horse in the Hatay province (near the Syrian border) by Mimioglu and Yarar (17) in 1961; H. scupense, D. marginatus and R. (Boophilus) annulatus were reported from cattle, buffalo, sheep, and goats by Parrish (18) in 1961; I. redikorzevi was reported from rodents by Nemenz (19) in 1967; Argas vespertilionis, O. tholozani, O. coniceps, I. hexagonus, I. laguri, I. frontalis, R. turanicus, R. (Boophilus) kohlsi, and Hyalomma marginatum were reported from either domestic animals or rodents throughout Turkey by Merdivenci (20) in 1969; and $H$. turanicum was reported from cattle by Hoffmann et al. (21) in 1971. Ten years later, Hae. otophila was reported by Sayin and Dumanli (22) in 1982; Hyalomma asiaticum was reported by Filippova et al. (23) in 1995; and Otobius megnini was detected from cattle in the Malatya province in Eastern Anatolia by Ozer and Aydin (24) in 1996. Recently, H. rufipes has been reported by Kar et al. (25) in 2009 from Marmara and by Bakirci et al. (26) in 2011 from cattle in the Aegean region. In addition to the above tick species, most recently, I. arboricola was identified in the Black Sea region (Cernek Ringing Station, Kizilirmak Delta, Samsun Province) by Keskin et al. (27) in 2014 from Turkey (Table 1).

Meanwhile, Turkey's tick fauna has been reviewed by Karaer et al. (28), Aydin and Bakirci (29), and Bursali et al. (30), but the number of tick species found was controversial. Briefly, eight soft tick species (Argas reflexus, A. persicus, A. vespertilionis; Ornithodoros lahorensis, O. tholozani, O. erraticus, O. coniceps; and Otobius megnini) in three genera belonging to Argasidae; thirty-nine hard tick species in six genera [Amblyomma variegatum; Dermacentor marginatus, D. niveus, D. reticulatus; Haemaphysalis concinna, Hae. erinacei, Hae. inermis, Hae. numidiana, Hae. otophila, Hae. parva, Hae. punctate, Hae. sulcata; Hyalomma aegyptium, $H$. anatolicum, $H$. excavatum, $H$. asiaticum, $H$. detritum, $H$. dromedari, $H$. impeltatum, $H$. marginatum, $H$. mauritanicum, $H$. scupense, $H$. rufipes, $H$. turanicum; Ixodes arboricola, I. frontalis, I. gibbosus, I. hexogonus, I. laguri, I. redikorzevi, I. ricinus, I. vespertilionis; Rhipicephalus (Boophilus) annulatus, R. (Boophilus) calcaratus, R. (Boophilus) kohlsi, R. bursa, $R$. rossicus, $R$. sanguineus, and $R$. turanicus] in Ixodidae have already been reported in the last hundred years of Turkey. Currently, Turkey's tick fauna comprises 47 species of classified and renamed world ticks by Guglielmone et al. $(31,32)$

\section{The geographical distribution of ticks}

Amblyomma variegatum was recorded as a solitary case in the Mediterranean region (border to Syria); Rhipicephalus (Boophilus) kohlsi and Otobius megnini are seen sporadically in Southeastern Anatolia. Ixodes spp. are mostly seen in the Black Sea and Marmara regions, Ornithodoros lahorensis is a prevalent tick 
Table 1. The chronologically reported tick species belonging to Argasidae and Ixodidae families from Turkey in the last century period between 1916 and 2016

\begin{tabular}{|c|c|c|c|c|c|}
\hline & Tick Species & Host & Location & Year & Reference \\
\hline \multirow{17}{*}{ IXODIDAE } & $\begin{array}{l}\text { Ixodes ricinus var. gibbosus n. var., Haemaphysalis } \\
\text { cinnabarina var. punctate, Hyalomma aegyptium }\end{array}$ & $\begin{array}{l}\text { Domestic goat } \\
\text { (Capra hircus) }\end{array}$ & Aegean region & 1916 & 7 \\
\hline & Ixodes ricinus & Sheep & All regions & 1926 & 8 \\
\hline & Rhipicephalus (Rhipicephalus) rossicus & unknown & Eastern Anatolia & 1946 & 10 \\
\hline & $\begin{array}{l}\text { Rhipicephalus bursa, R. sanguineus, R. (Boophilus) } \\
\text { calcaratus, H. dromedarii, H. anatolicum, Hae. } \\
\text { concinna, Dermacentor reticulatus }\end{array}$ & Livestock & Central Anatolia & 1944 & 11,50 \\
\hline & $\begin{array}{l}\text { Hae. parva, Hae. inermis, Hae. sulcata, } \\
\text { Hae. numidiana, D. niveus, H. detritum, H. excavatum }\end{array}$ & $\begin{array}{l}\text { Domestic } \\
\text { animals }\end{array}$ & All regions & 1954 & 81 \\
\hline & H. mauritanicum & Cattle & Marmara region & 1954 & 13 \\
\hline & I. vespertilionis & $\begin{array}{l}\text { Vespertilian } \\
\text { bats }\end{array}$ & $\begin{array}{l}\text { Aegean region, } \\
\text { Mediterranean region, } \\
\text { Eastern Anatolia }\end{array}$ & 1956 & 15 \\
\hline & Hae. erinacei, H. impeltatum & Hedgehog & Marmara region & 1959 & 16 \\
\hline & Ablyomma variegatum & Horse & Mediterranean region & 1961 & 17 \\
\hline & $\begin{array}{l}\text { H. scupense, D. marginatus, R. (Boophilus) } \\
\text { annulatus }\end{array}$ & $\begin{array}{l}\text { Cattle, buffalo, } \\
\text { sheep, goats }\end{array}$ & All regions & 1961 & 18 \\
\hline & I. redikorzevi & Rodents & $\begin{array}{l}\text { Black Sea region, } \\
\text { Eastern Anatolia }\end{array}$ & 1967 & 19 \\
\hline & $\begin{array}{l}\text { I. hexagonus, I. laguri, I. frontalis, R. turanicus, } \\
\text { R. (Boophilus) kohlsi, H. marginatum }\end{array}$ & $\begin{array}{l}\text { Domestic animals } \\
\text { and rodents }\end{array}$ & All regions & 1968 & 20,79 \\
\hline & H. turanicum & Cattle & $\begin{array}{l}\text { Central Anatolia, } \\
\text { Black Sea region }\end{array}$ & 1971 & 21 \\
\hline & Hae. otophila & Cattle & Eastern Anatolia & 1982 & 22 \\
\hline & H. asiaticum & Cattle & South Eastern Anatolia & 1995 & 23 \\
\hline & H. rufipes & Cattle & $\begin{array}{l}\text { Marmara and } \\
\text { Aegean regions }\end{array}$ & 2009 & 25,26 \\
\hline & I. arboricola & Birds & Black Sea region & 2014 & 27 \\
\hline \multirow{5}{*}{ ARGASIDAE } & Ornithodoros lahorensis & Sheep/goats & Eastern Anatolia & 1936 & $9,49,52,53$ \\
\hline & Argas reflexus, A. persicus & Domestic animals & All regions & 1954 & 12 \\
\hline & O. erraticus & Rodents & South Eastern Anatolia & 1954 & 14 \\
\hline & Argas vespertilionis, O. tholozani, O. coniceps & $\begin{array}{l}\text { Domestic animals } \\
\text { and rodents }\end{array}$ & All regions & 1968 & 20,79 \\
\hline & Otobius megnini & Cattle & Eastern Anatolia & 1996 & 24 \\
\hline
\end{tabular}

species in Central and Eastern regions of Anatolia, and the remaining species belonging to Dermacentor, Haemaphysalis, Hyalomma, Rhipicephalus and as well Argas are seen widespread throughout Anatolia. In addition, the ecology of Hyalomma marginatum has been particularly investigated because of the Crimean Congo Hemorrhagic Fever that endemically occurred in areas of Turkey (33). The often-seasonal activities of ticks were also reported as Rhipicephalus species [except $R$. (Boophilus) annulatus] and were generally seen from early to late spring, and sometimes in summer periods, in the all regions while R. (Boophilus) annulatus generally infests its host between September and December in Central Anatolia (34, 35); Hyalomma species were frequently found in the seasons between late spring and early autumn in the countryside; Dermacentor spp. were observed in winter periods in the all regions (29); Haemaphysalis spp. were reported generally in autumn from throughout the country; Ixodes spp. were frequently seen yearround in the Marmara, Aegean, Mediterranean, and Black Sea regions $(29,36)$. Except $O$. megnini, the other argasid ticks Argas and Ornithodoros species were generally found throughout the year in most parts of Turkey (29). In the Kayseri area of Central Anatolia, Hyalomma spp. and R. (Boophilus) annulatus were the most prevalent ticks found for cattle infestations. In this area, the seasonal fluctuation of tick species was determined as follows: 
Rhipicephalus spp. (in spring, summer, and fall); the adults of Hyalomma spp. (in spring, peaking in summer, and in autumn); Haemaphysalis spp. (in autumn, winter, and early spring); $O$. lahorensis (in autumn, peaking in winter, and in spring); Dermacentor marginatus (in all seasons); and R. (Boophilus) annulatus (in spring) (35). On the other hand, the seasonal fluctuation of $H$. scupense and its infestation characteristics was specifically monitored on the infested cattle and also in the infested barns through two tick seasons in the Thrace region of Turkey (37).

\section{Tick infestations in animals and man}

In parallel to these taxonomic, distribution, and seasonal studies on ticks, numerous surveys have been conducted on the medical and veterinary importance of ticks throughout Turkey. In this scope, tick infestations have been reported in livestock animals, such as cattle $(3,11,22,35,37-54)$; sheep and goats $(11,34,36$, $42,46,47,49-53,55-62)$; in horses $(17,63-65)$; in man $(11,37,50$, $51,66-80)$; in poultry $(12,20)$; in birds $(27,81,82)$; in bats $(83)$; in foxes $(20)$; and in reptiles $(84,85)$. Additionally, an aberrant tick infestation case has been observed in a man who had just returned to Turkey from a safari trip in Africa, and the removed tick was identified as Amblyomma spp. nymph (86).

\section{Control measures for ticks}

Integrated tick control strategies are very important to reduce the direct effects of ticks and also to prevent the transmission of TBDs in the country, as well as globally. Integrated tick control measures consist of environmental, personal, and prophylactic controls (87). In the last century in Turkey, environmental tick control measures have been applied depending on intensive chemical usage. The direct application of chemical acaricides is the most popular tick control measure in Turkey, as well as globally. Arsenicals were the first used acaricide for the global tick control and were first used against Boophilus spp. infestations in cattle in 1893 in South Africa. Generally, $\mathrm{As}_{2} \mathrm{O}_{3}$ was used against tick infestation for many years in Turkey as well as globally (88). After ticks developed resistance against this acaricide, the usage of this chemical was stopped in the beginning of the 1980s (89, 90). Subsequently, chlorinated hydrocarbons, organophoshorous compounds, carbamates, formamidines, synthetic pyrethroids, phenyl pirazols, macrocyclic lactones (MLs), and growth regulators were used for tick control in Turkey. Currently, formamidines, synthetic pyrethroids, phenyl pirazols, and MLs are used for tick control in Turkey. On the other hand, personal tick control is also used generally in rural areas and in some urban areas of Turkey. Personal tick control strategies depend on measures such as avoiding scrublands, wearing white or light-colored clothing, pulling socks over the bottom of pant legs, walking in the center of walkways and paths, avoiding roadside grass, wearing lotions (except the face and hands) containing 30\% diethyltoluamide (DEET) as a repellent, wearing special permethrin-impregnated clothing, and daily tick control in the bathroom after each field trip. Recently, these kinds of personal tick control measures were frequently applied by some sensitive humans in Turkey. Another tick control measure is prophylactic tick control. This tick control measure has some different characteristics, requires advanced technology, and is applied through biological controls such as tick vaccines and RNA interference. No study has been reported about the applying of prophylactic tick control in Turkey as of yet.

In conclusion, Turkey has a suitable geographic location, warming climate conditions, and many bird paradises that serve as a bridge for migratory birds from Africa to Europe and from Europe to Africa. This natural structure allows exposure of Turkey to many tick infestations in animals and also in humans across the different regions of the country. Today, a total of 47 tick species ( 8 soft and 39 hard ticks) have already been reported in animals and humans from seven major regions of Turkey throughout the past century (between 1916 and 2016). Therefore, Turkey requires new strategies and advanced control programs for integrated tick control. Thus, Turkey should also develop and maintain coordination with internal and international organizations for future safety.

Peer-review: Externally peer-reviewed.

Author Contributions: Concept - A.I., A.Y., O.D.; Design - A.I., A.Y., O.D.; Supervision - A.I., A.Y., O.D.; Funding - A.I., A.Y., O.D.; Materials A.I., A.Y.,O.D.; Data Collection and/or Processing - A.I; Analysis and/or Interpretation - A.I, A.Y.,O.D.; Literature Review - A.I., A.Y., O.D.; Writing - A.I.; Critical Review - A.I., A.Y., O.D.; Other - A.I., A.Y., O.D.

Conflict of Interest: No conflict of interest was declared by the authors.

Financial Disclosure: The authors declared that this study has received no financial support.

Hakem değerlendirmesi: Dış bağımsız.

Yazar Katkıları: Fikir - A.I, A.Y. ,Ö.D.; Tasarım - A.I, A.Y., Ö.D.; Denetleme - A.I, A.Y., Ö.D.; Kaynaklar - A.I., A.Y., Ö.D.; Malzemeler - A.I., A.Y., Ö.D.; Veri toplanması ve/veya işlemesi - A.I.; Analiz ve/veya yorum - A.I., A.Y., Ö.D.; Literatür taraması - A.I, A.Y., Ö.D.; Yazıyı yazan - A.I.; Eleştirel Inceleme - A.Y., Ö.D.; Diğer - A.İ, A.Y., Ö.D.

Çıkar Çatışması: Yazarlar çıkar çatışması bildirmemişlerdir.

Finansal Destek: Yazarlar finansal destek almadıklarını beyan etmişlerdir.

\section{REFERENCES}

1. Inci A, Yazar S, Tuncbilek AS, Canhilal R, Doganay M, Aydin L, et al. Vectors and vector-borne Diseases in Turkey. Ankara Univ Vet Fak Derg 2013; 60: 281-96. [CrossRef]

2. Inci A, Yildirim A, Duzlu $O$. Three emerging vector-borne diseases in Turkey. J Fac Vet Med Univ Erciyes 2014; 11: 117-20.

3. Inci A, Ica A, Yildirim A, Vatansever Z, Cakmak A, Albasan H, et al. Economical impact of tropical theileriosis in the Cappadocia region of Turkey. Parasitol Res 2007a; 101: S171-4. [CrossRef]

4. Jongejan F, Uilenberg G. The global importance of ticks. Parasitol 2004; 129: S3-S14. [CrossRef]

5. Bram RA. Tick-borne livestock diseases and their vectors: the global problem. Ticks and Tick-Borne Diseases, FAO Animal Production and Health Paper No. 36. Rome: Food and Agriculture Organization; 1983.

6. McCosker PJ. Global aspects of the management and control of ticks of veterinary importance. Recent Adv Acarol 1979; 2: 45-53. [CrossRef]

7. Nuttall GHF. Notes on Ticks. IV. Relating to the Genus Ixodes and including a description of three new species and two new varieties. Parasitology 1916; 8: 294-337. [CrossRef]

8. Celebi IH. Ixodidae (keneler) ve muvellidimaraz vazifeleri tahripleri (ixodid ticks and their harmful effects). Tibbi Bay Mec 1926; 3: 261-71. 
9. Tuzdil AN. Mezbahalara Mahsus Parazitoloji. Istanbul; 1936.

10. Pomerantzev BI. Les tiques (Ixodidae) de la faune de L'URSS et des pays limitrophes. Opredeliteli po Faune SSSR, Izdavaemye Zoologicheskim Institutom Akademii Nauk SSSR 1946; (26): 1-28.

11. Oytun HS. Keneler, Zararlari ve Savas Careleri. Ankara: YZE Basimevi; 1947.

12. Kurtpinar H. Turkiye keneleri (Ixodoidea). Morfoloji, Biyoloji, Konakci, Yayilislari ve Medikal Onemleri. Ankara: Guven Matbaasi; 1954.

13. Yasarol S. Sigirlarda kene kontrolunde toxophane. Turk Vet Hek Dern Derg 1954; 24: 1756-66.

14. Ozsan K, Akyay N. Relapsing fever in Turkey; presence in the South (Turko-Syrian border) of Ornithodorus erraticus infected with a spirochete of the Crocidurae group. Bull Soc Pathol Exot Filiales 1954; 47: 501-3.

15. Arthur DR. The Ixodes ticks of Chiroptera (Ixodoidea, Ixodidae). J Parasitol 1956; 42: 180-96. [CrossRef]

16. Hoogstraal H. Biological observations on certain Turkish Haemaphysalis ticks (Ixodoidea, Ixodidae). J Parasitol 1959; 45: 227-32. [CrossRef]

17. Mimioglu M, Yarar MT. Turkiye'de ilk Amblyomma variegatum Fabricius, 1974 olayi. Ank Univ Vet Fak Derg 1961; 8: 239-40.

18. Parrish DW. The ticks (Argasidae and Ixodidae) of Turkey. J Econ Entomol 1961; 54: 91-2. [CrossRef]

19. Nemenz H. Zecken aus der Turkei (Acari, Ixodidae). Zool 1967; 178: 191-5.

20. Merdivenci A. Turkiye Keneleri Uzerine Arastirmalar. Istanbul: Istanbul Cerrahpasa Tip Fak Yayini, Yayin No 1488, Kutulmus Matbaasi; 1969.

21. Hoffmann G, Horchner F, Schein E, Gerber H. Saisoneles auftreten von Zecken und Piroplasmen bei Haustieren in den Asiatischen Provinzen der Turkei. Berl Munch Tierarztl Wochenschr 1971; 94: 152-6.

22. Sayin F, Dumanli N. Elazig bolgesi evcil hayvanlarda gorulen kene (Ixodidae) turleri ile ilgili epizootiyolojik arastirmalar. Ank Univ Vet Fak Derg 1982; 29: 344-62.

23. Filippova NA, Musatov SA, Panova IV, Lobanov AL. The taxonomic pattern of the polytypic species Hyalomma asiaticum (Ixodidae). First experience of morphometric databases application. Parazitologiya 1995; 29: 65-82.

24. Ozer E, Aydin L. Presence of Otobius megnini (Duges, 1883) in cattle in Malatya. Turk J Vet Anim Sci 1996; 20: 231-4.

25. Kar S, Guven E, Vatansever Z. Marmara Bolgesindeki bir harada kene enfestasyonu ve Hyalomma rufipes varligi. 16. Ulusal Parazitoloji Kongresi; Kasim; 1-7; Adana: 2009. p. 254.

26. Bakirci S, Sarali H, Aydin L, Latif A, Eren H, Karagenc T. Hyalomma rufipes (Koch, 1844) infesting cattle in the West Aegean region of Turkey. Turk J Vet Anim Sci 2011; 35: 359-63.

27. Keskin A, Koprulu TK, Bursali A, Ozsemir AC, Yavuz KE, Tekin S. First record of Ixodes arboricola (Ixodida: Ixodidae) from Turkey with presence of Candidatus Rickettsia vini (Rickettsiales: Rickettsiaceae). J Med Entomol 2014; 51: 864-7. [CrossRef]

28. Karaer Z, Yukarı BA, Aydin L. Turkiye keneleri ve vektorlukleri. Ozcel MA, Daldal N, editors. Parazitoloji'de Artropod Hastaliklari ve Vektörler. Izmir: Ege Univ Basimevi; 1997. p. 363-458.

29. Aydin L, Bakirci S. Geographical distribution of ticks in Turkey. Parasitol Res 2007; 101: S163-6. [CrossRef]

30. Bursali A, Keskin A, Tekin S. A review of the ticks (Acari: Ixodida) of Turkey: species diversity, hosts and geographical distribution. Exp Appl Acarol 2012; 57: 91-104. [CrossRef]

31. Guglielmone AA, Robbins RG, Apanaskevich DA, Petney TN, Estrada-Pena A, Horak IG, et al. The Argasidae, Ixodidae and Nuttalliellidae (Acari: Ixodida) of the world: a list of valid species names. Zootaxa 2010; 2528: 1-28.
32. Guglielmone AA, Robbins RG, Apanaskevich DA, Petney TN Estrada-Pena A, Horak IG. The hard Ticks of the World (Acari: Ixodida: Ixodidae). New York: Springer; 2014. [CrossRef]

33. Vatansever Z. Ecology of Hyalomma marginatum and CrimeanCongo hemorrhagic fever. 1st National Symposium on Vectors and Vector Borne Diseases with International Participation; September; 9-10; Avanos, Cappadocia, Nevsehir-Turkey: 2012. p. 44-59.

34. Sayin F, Dincer $S$, Karaer Z, Dumanli N, Cakmak A, Inci A, et al. Status of tick infestations of sheep and goats in Turkey. Parassitologia 1997; 39: 145-52.

35. Ica A, Inci A, Vatansever Z, Karaer Z. Status of tick infestation of cattle in the Kayseri region of Turkey. Parasitol Res 2007; 101: S167. 9. [CrossRef]

36. Aydin MF, Aktas M, Dumanli N. Turkiye'nin Karadeniz bolgesindeki koyun ve kecilerde kene enfestasyonlari. Kafkas Univ Vet Fak Derg 2012; 18: A17-22.

37. Kar S, Akyildiz G, Vatansever Z. Trakya'da ineklerde Hyalomma scupense enfestasyonu ve enfestayonun mevsimsel karakteristigi. 19. Ulusal Parazitoloji Kongresi ve Uluslararasi katilimli Ekinokokozis Sempozyumu; Ekim; 5-9; Erzurum: 2015a. p. 79.

38. Goksu K. Bazi Karadeniz Bolgesi illerinin sigirlarinda musahade edilen Babesidae (Sporozoa: Piroplasmida) enfeksiyonlari ve kene enfestasyonlari. Ank Univ Vet Fak Derg 1968; 15: 46-57.

39. Dumanlı N. Elazig ve yoresinde Hyalomma excavatum (Koch, 1844)'un biyo-ekolojisi uzerinde arastirmalar. Tubitak Doga Bilim Derg 1983; 7: 23-31.

40. Karaer Z. Ankara ili ve civarinda bulunan kene turleri ile Hyalomma detritum (Schulze, 1919)'un bazi ekolojik ozellikleri uzerine arastirmalar. Tubitak 7. Bilim Kongresi Tebligleri, Turkiye: 1983. p. 371-8.

41. Zeybek H, Kalkan A. Ankara yoresinde mera kenelerinin yayilisi ve mevsimle iliskisi. Etlik Vet Mikrobiyol Enst Derg 1984; 5: 14-21.

42. Tasci S. Van bolgesinde sigir ve koyunlarda gorulen kene turleri ile bunlarin tasidigi kan parazitleri (protozoon) arasindaki iliskiler. Ank Univ Vet Fak Derg 1989; 36: 53-63.

43. Inci A. Ankara'nın Cubuk ilcesinde sigirlarda babesiosis'in seroinsidensi uzerine arastirmalar. Ankara Univ Vet Fak 1992; 1-2: 153-67.

44. Inci A, Cakmak A, Karaer Z, Dincer S, Sayin F, Ica A. Seroprevalence of bovine babesiosis around Kayseri. Turk J Vet Anim Sci 2002a; 26: 1345-50.

45. Inci A, Ica A, Yildirim A, Vatansever Z, Cakmak A, Albasan H, et al. Epidemiology of tropical theileriosis in Cappadocia region. Turk $J$ Vet Anim Sci 2008; 32: 57-64.

46. Yukari BA, Umur S. Burdur yoresindeki sigir, koyun ve kecilerde kene (Ixodidae) turlerinin yayilisi. Turk J Vet Animal Sci 2002; 26: 1263-70.

47. Aydin L. Guney Marmara Bolgesi ruminantlarinda gorulen kene turleri ve yayilislari. T Parazitol Derg 2002; 24: 194-200.

48. Kar S, Akyildiz G, Vatansever Z. Kirklareli'nde CCHF olgularina rastlanan koylerdeki ineklerde kene enfestasyonunu mevsimsel karakteristigi. 19. Ulusal Parazitoloji Kongresi ve Uluslararasi katilimli Ekinokokozis Sempozyumu; Ekim; 5-9; Erzurum: 2015b. p. 76.

49. Oytun HS. Memleketimizde gorulen O. lahorensis Neumann, 1908 morfolojisi ve biyolojisine dair yapilmis arastirmalar. YZE Derg 1944a; 3: 175-88.

50. Oytun HS. Kenelerin dis parazit olarak insan ve ehli hayvanlarda yaptiklari zararlar. Guzel Yurd Gazetesi 1944b; 31: 14/1/1944.

51. Oytun HS. Kenelerin yaptıklari cesitli zararlar. TVC Derg 1944c; 12: 2.

52. Oytun HS. Ornithodorus lahorensis biyolojisi ve ve yayilisina dair. TC Tarim Bak Derg 1948; 15: 10-12.

53. Oytun HS. Yurdumuzda gorulen Ornithodorus lahorensis'in epidemiyolojik durumu ve bu alandaki arastirmalarimiz. TC Tarim Bak Derg 1949; 18: 8-12.

54. Oytun HS. Tibbi Entomoloji. Ank Univ Tip Fak Yayin, Ikinci Baski, Guzel Istanbul Matbaasi, Ankara, 1961, p. 546. 
55. Guralp N, Sayin F, Tigin Y, Tinar R. Texel, Merinos ve Kivircik koyunlari ile melezlerinde gorulen parazit turleri, bunlarin enfeksiyon orani ve savas careleri. Ankara Univ Vet Fak Derg 1975; 22: 1-17. [CrossRef]

56. Guler S. Ankara ve civarindaki koyun ve kecilerde kis Ixodiddae'leri uzerine arastirmalar. Bursa Univ Vet Fak Derg 1982; 1: 45-54.

57. Kalkan A. Koyun kis kenesi (Ornithodoros lahorensis Neumann, 1908)'nin ekolojisi ve vektorlugu uzerine incelemeler. Ank Univ Vet Fak Derg 1982; 29: 331-43.

58. Cakmak A, Dincer S, Karaer Z. Samsun yoresinde koyunlarda Babesia ovis'in serodiagnosu uzerinde arastirmalar. Ankara Univ Vet Fak Derg 1991; 38: 242-51.

59. Ozer E, Guler S. The occurence of Boophilus kohlsi (Hoogstraal \& Kaiser, 1990) in goats in Mardin. Doga Tr Vet Animal Sci 1993; 18: 23-6.

60. Inci A, Yukari B, Sayin F. Cankiri yoresinde bazı koyun ve keci surulerinde babesiosis ve theileriosis etkenlerinin mikroskobik kan muayenesiyle arastirilması. Ank Univ Vet Fak Derg 1998; 1: 105-13.

61. Inci A, Nalbantoglu S, Cam Y, Atasever A, Karaer Z, Cakmak A, et al. Kayseri yoresinde koyun ve kecilerde theileriosis ve kene enfestasyonlari. Turk J Vet Anim Sci 2003; 27: 57-60.

62. Cicek H, Duzgun A, Emre Z, Karaer Z. Seroprevalence of Babesia ovis in sheep around Afyon. Turk J Vet Anim Sci 2004; 28: 683-6.

63. Inci A. Gemlik askeri harasi atlarında Babesia caballi (Nuttall, 1910) ve Babesia equi (Laveran, 1901)'nin mikroskobik muayeneyle saptanmasi. Turk J Vet Anim Sci 1997; 21: 43-6.

64. Aktas M, Dumanli N. Malatya Sultansuyu Tarim isletmesi atlarinda subklinik Babesia equi (Laveran, 1901) ve Babesia caballi (Nuttall, 1910) enfeksiyonlari. Turkiye Parazitol Derg 2000; 24: 55-6.

65. Kizilarslan F, Yildirim A, Duzlu, O, Inci A, Onder Z, Ciloglu A. Molecular detection and characterization of Theileria equi and Babesia caballi in horses (Equus ferus caballus) in Turkey. J Equine Vet Sci 2015; 35: 830-5. [CrossRef]

66. Inci A, Ica A, Duzlu O, Yildirim A, Biskin Z. Kayseri, Nevsehir, Nigde, Hatay, Adana, Osmaniye, Kahramanmaras ve Gaziantep illerinde insanlarda gorulen kene enfestasyonlari. 15. Uluslararasi Parazitoloji Kongresi; Kasim; 18-23; Kayseri ve Urgup: 2007b. p. 167-8.

67. Umur S, Hokelek M, Acici M, Gurler AT, Beyhan YM. Orta karadeniz bolgesinde insanlarda isirik sikayetiyle getirilen kene turleri. 15. Ulusal Parazitoloji Kongresi; Kasim; 18-23; Kayseri ve Urgup: 2007. p. 167.

68. Vatansever Z, Uzun R, Estrada-Pena A, Ergonul O. Crimean-Congo hemorrhagic fever in Turkey. Ergonul O, Whitehouse CA, editors. Crimean-Congo Hemorrhagic Fever: A Global Perspective. New York: Springer, Dordrecht; 2007. [CrossRef]

69. Vatansever Z, Gargili A, Aysul NS, Sengoz G, Estrada-Peña A. Ticks biting humans in the urban area of Istanbul. Parasitol Res 2008; 102: 551-3. [CrossRef]

70. Gargili A, Kar S, Yilmazer N, Cerit C, Sonmez G, Sahin F, et al. Evaluation of ticks biting humans in Thrace Province, Turkey. Kafkas Univ Vet Fak Derg 2010; 16: S141-6.

71. Gargili A, Kar S, Yilmazer N, Ergonul O, Vatansever Z. Different abundances of human-biting ticks in two neighboring provinces in Turkey. Kafkas Univ Vet Fak Derg 2011; 17: 93-7.
72. Gunes T, Poyraz O, Vatansever Z. Crimean-Congo hemorrhagic fever virus in ticks collected from humans, livestock, and picnic sites in the hyper endemic region of Turkey. Vector Borne Zoonotic Dis 2011; 11: 1411-6. [CrossRef]

73. Aktas M. A survey of ixodid tick species and molecular identification of tick-borne pathogens. Vet Parasitol 2014; 200: 276-83. [CrossRef]

74. Orkun O, Karaer Z, Cakmak A, Nalbantoglu S. Identification of tickborne pathogens in ticks feeding on humans in Turkey. Plos NTD 2014a; 8: e3067. [CrossRef]

75. Orkun O, Karaer Z, Cakmak A, Nalbantoglu S. Spotted fever group rickettsiae in ticks in Turkey. Ticks Tick-borne Dis 2014b; 5: 213-8. [CrossRef]

76. Selcuk O, Aydin L, Girisgin AO, Senlik B, Ozakin C. Long-term investigations on tick infestations of human. Kafkas Univ Vet Fak Derg 2015; 21: 795-8.

77. Merdivenci A. Turkiye'nin entomolojik cografyasi (Turkiye'nin parazitolojik cografyasi, s. 114-192). Ege Univ Tıp Fak Yayini 1965; No. 42. Izmir.

78. Merdivenci A. Turkiye'de kene larvalari üzerine arastirmalar. VI MT Biol Kongr 15-21 Agustos, Izmir, 1966, s. 251-68.

79. Merdivenci A. Istanbul'da insanlarda Ornithodorus conciceps Canestrini, 1890 infestasyonu. Turk Mikrobiol cem 30.5.1968 gunku toplantisinda bildirilmistir. IU Tıp Fak Mec 1968; 31: 460-68.

80. Mimioglu MM. Veteriner ve Tibbi Arthropodoloji. Ank Univ. Vet Fak Yayin, No.295, Ders Kitabı. 196, Ank Univ Matbaasi, Ankara 1973, p. 343.

81. Kurtpinar H. Anadolu'da Argas reflexus Fabr. (guvercin kenesi)'nin insanlarda tevit ettigi sihhi bozukluklar uzerine arastirmalar. Turkish Bull Hyg Exp Bio 1957; 17 (3): 237-43.

82. Leblebicioglu H, Eroglu C, Erciyas-Yavuz K, Hokelek M, Acici M, Yilmaz $\mathrm{H}$. Role of migratory birds in spreading Crimean-Congo hemorrhagic fever. Turk Emerg Infect Dis 2014; 20: 1331e1334.

83. Sert H, Yagci S, Albayrak I, Aktas M, Karaer Z. Turkiye'nin farkli bolgelerinden yakalanan yarasalarda (Vespertilionidae, Rhinolophidae) kene (Acari: Ixodidae, Argasidae) enfestasyonu. T Parazitol Derg 2001; 25: 174-7.

84. Aydin L, Yildirimhan HS, Ugurtas IH. Marmara Bolgesindeki bazi kertenkele ve kablumbaga turlerinde kenelerin (Ixodidae) yayginligi. T Parazitol Derg 2002; 26: 84-6.

85. Yaman M, Zerek A. Bir Akdeniz Bukalemunu'nda (Chamaeleo chamaeleon) Rhipicephalus (Boophilus) kohlsi (Hoogstraal and Kaiser, 1960) Olgusu. FÜ Sağ Bil Derg 2016; 30: 55-6.

86. Beyhan YE, Mungan M, Babur C. Yurtdisi seyahat iliskili Amblyomma spp. olgusu (Amblyomma spp. case related to overseas travel). Turkiye Parazitol Derg 2014; 38: 48-50. [CrossRef]

87. Walker AR. Eradication and control of livestock ticks: biological, economic and social perspective. Parasitol 2011; 138: 945-59. [CrossRef]

88. Bekker PM. The history of dipping. Veld 1960; 20: 1-5.

89. Matthewson MD, Baker JAF. Arsenic resistance in species of multihost ticks in the Republic of South Africa and Swaziland. J S Afr Vet Assoc 1975; 46: 341-4.

90. Drummond RO. Tick-borne livestock diseases and their vectors. Chemical control of ticks. Wld Anim Rev (FAO) 1983; 36: 28-33. 